Short communication

\title{
ULTRASTRUCTURAL CHANGES IN THE CYCLIC CORPUS LUTEUM OF DAIRY COWS WITH DIFFERENT BODY CONDITION
}

\author{
PIVKO Juraj ${ }^{1}$, MAKAREVICH V. Alexander ${ }^{1 *}$, KUBOVIČOVA Elena ${ }^{1}$, \\ RAFAY Jan ${ }^{1,2}$, CHRENEK Peter ${ }^{1,3}$
}

\begin{abstract}
${ }^{1}$ Research Institute for Animal Production Nitra, National Agricultural and Food Centre, Hlohovecka 2, 95141 Lužianky-near-Nitra, Slovak Republic; ${ }^{2}$ University of Ss. Cyril and Methodius in Trnava, Nam. J. Herdu 2, 91701 Trnava, Slovak Republic; ${ }^{3}$ Slovak University of Agriculture, Tr.A.Hlinku 1, 94901 Nitra, Slovak Republic
\end{abstract}

(Received 28 August 2015; Accepted 26 April 2016)

The aim of the study was to define ultrastructural changes in the ovarian cyclic corpus luteum (CL) of dairy cows with different body condition score (BCS, a 5-point scale). The ovaries were recovered from slaughtered Holstein cows of BCS1 (emaciation; $n=$ 4), BCS2 (tendency to emaciation; $n=4$ ), BCS3 (average body condition; $n=4$ ), BCS4 (tendency to fattening; $n=4$ ) and BCS5 (fattening; $n=4$ ). Average ages of cows were: 6.2, $4.1,5.7,5.5$ and 6.36 years for BCS1, BCS2, BCS3, BCS4 and BCS5, respectively. For electron microscopy, functioning CL at the mid-luteal phase were fixed in the aldehyde solution and post-fixed in 1\% OsO4 solution. For lipid visualization the samples were soaked in 1\% p-phenylenediamine solution in acetone. Durcupan ultrathin sections $(90 \mathrm{~nm})$ were contrasted with uranyl acetate and lead citrate and viewed under Jeol transmission electron microscope. Occurrence of cell organelles was determined by counting the relative volume of individual cellular components using the modified universal test network. Luteal regression of cyclic CL was characterized by atrophy of lutein cells, condensation of organelles and cytoplasmic inclusions, increase in relative volumes of vacuoles, lysosomes, peroxisomes, autophagosomes and lipids. There were significant differences $(\mathrm{p}<0.05)$ among BCS1, BCS2, BCS4 and BCS5 cows in the occurrence of lipids, vacuoles, lysosomes and autophagosomes in the lutein cells compared to BCS3 cows. Cows with BCS2 or BCS1 had higher relative volume of lipid droplets, whilst the BCS4 or BCS5 cows had increased occurrence (relative volume) of vacuoles, lysosomes, peroxisomes and autolysosomes. These results show that luteolysis of cyclic CL of cows has different patterns in each BCS group; in the emaciated and fattened cows luteolysis starts earlier than in cows with average body condition.

Key words: body condition score, cattle, emaciation, fattening, luteal regression

\section{INTRODUCTION}

Luteolysis of the cyclic corpus luteum is an essential event for the progression of the ovulatory cycle [1]. If the oocyte after ovulation is not fertilized, the corpus *Corresponding author: e-mail: makarevic@vuzv.sk 
luteum degenerates [2]. Regressive corpora lutea are characterized by a decrease in progesterone production (functional luteolysis), which induces apoptosis of luteal cells (structural luteolysis) [3]. Lutein cells of bovine CL have all signs of steroidproducing cells, active corpus luteum and highest rate of progesterone secretion [4]. The ultrastructural image is characterized by a large amount of smooth endoplasmic reticulum, mitochondria with cristae and numerous lipid droplets [5]. Morphology and function of cyclic corpora lutea from cows with different body condition score (BCS) is described in the available literature insufficiently. Corpus luteum of low quality and functional activity produces progesterone at low levels thus decreasing cow fertility $[6,7]$.

Ovarian functions of dairy cows are greatly influenced by metabolic disorders caused by nutrition (energy deficit), which are resulted in the gonadotropin level disorders [8]. Usually, ovulation disorders are caused by the decrease in the LH level, worsening the quality of CL and reducing luteal phase thereby initiating a short cycle [9]. Changes in bone morphogenetic protein 15(BMP-15) and growth differentiation factor 9 (GDF9) concentrations may lead to folliculogenesis disorders 10]. These changes lead to premature regression of the corpus luteum in the form of functional and structural luteolysis with a strong signs of atrophy and autophagic changes in the lutein cells. In this area no available literature has been published yet. Therefore, the goal of our study was to examine changes in the cell ultrastructure of ovarian cycling corpora lutea from dairy cows of various body conditions.

\section{MATERIAL AND METHODS}

\section{Biological material}

As a source of biological material, the ovaries were recovered at slaughtering of dairy cows $(n=20)$ of Holstein breeds at a local abattoir. The cows had no pathological changes on organs and were kept under normal feed regime. The animals were estimated as belonging to a certain grade of body condition score (BCS) according to a 5-point scale of BCS [11]. For our experiments dairy cows of BCS1 (emaciation; $\mathrm{n}=$ 4), BCS2 (tendency to emaciation; $n=4$ ), BCS3 (optimal body condition status; $n=4$ ), BCS4 (tendency to fattening; $n=4$ ) and BCS5 (fattening; $n=4$ ) were available. The data on these cows were taken from cow's individual cards on farms and average age was 6.2 years, 4.1 years, 5.7 years, 5.5 years and 6.36 years for BCS1, BCS2, BCS3, BCS4 and BCS5, respectively. Cycling corpora lutea (CL) were collected at a mid-stage (9-14 days after ovulation) and analyzed for cell ultrastructure using electron microscopy technique.

\section{Ultrastructural analysis}

The samples of corpora lutea from cows of BCS 1-5 were fixed in the aldehyde mixture $(2.5 \%$ glutaraldehyde and $2 \%$ paraformaldehyde in $0.1 \mathrm{M}$ sodium cacodylate) at $4{ }^{\circ} \mathrm{C}$ for 1 hour and subsequently post-fixed in $1 \% \mathrm{OsO}_{4}$ in $0.1 \mathrm{M}$ sodium cacodylate for 1 hour. The samples were soaked in 1\% p-phenylenediamine (Sigma-Aldrich) 
solution in $70 \%$ acetone for 30 min according to [12] for lipid visualization. After the dehydration in acetone the samples were embedded into Durcupan ACM (Fluka). Ultrathin sections $(90 \mathrm{~nm})$ were cut using a Leica EM UC6 ultramicrotom (MIKRO Ltd., Bratislava, Slovak Republic) and then contrasted with 10\% uranyl acetate solution in absolute methanol and lead citrate to visualize cell organelles. The obtained contrasted sections were analyzed under a JEM100 CXII transmission electron microscope (Jeol, Japan) at accelerating voltage of $80 \mathrm{kV}$.

\section{Ultrastructural morphometry}

We determined the changes in the ultrastructure of important cell organelles (lipid droplets, cytoplasmic vacuoles, lysosomes, peroxisomes, autophagosomes and lipofuscin pigment granules) in the corpus luteum sections. Lipids were visualized using 1\% p-phenylenediamine solution (mentioned above), but their occurrence was quantified by counting a relative volume of lipid droplets. On the basis of morphometric evaluation lysosomes were identified as dark electronoptic dense bodies of 0.2-0.5 microns in diameter, surrounded by a membrane. In contrast to lysosomes, peroxisomes were represented by light electronoptic microbodies of 0.1-0.2 microns in diameter, surrounded by a membrane and contained very fine granular matter.

The electronograms $(n=50)$ for ultastructural morphometry were made from ultrathin sections at primary magnification of 7200x. Occurrence of cell organelles was determined by counting the relative volume of individual cellular components using the modified universal test network with 154 points. The electronograms were evaluated by stereological analysis according to Weibel [13].

\section{Statistics}

Data for ultrastructural changes in lutein cells of corpora lutea were statistically evaluated by one-way ANOVA (Holm-Sidak method) using SigmaPlot software (Systat Software Inc., Germany) and expressed as the means \pm SEM; different letters indicate significant differences ( ${ }^{\mathrm{a}}$ vs. ${ }^{\mathrm{b}}$ at $\mathrm{P}<0.001$ and ${ }^{\mathrm{c}}$ vs. ${ }^{\mathrm{d}}$ at $\left.\mathrm{P}<0.01\right)$ among the means in each column with the same parameter.

\section{RESULTS}

\section{Ultrastructure of luteal cells from cows of BCS1/ BCS2 (emaciation)}

The cytoplasm of lutein cells of dairy cows contained swollen mitochondria with lysis of cristae and membrane rupture. Often in their vicinity peroxisomes occurred (Fig. 1A). Smooth endoplasmic reticulum forms numerous vesicles of various sizes, which are fused into large vacuoles (Fig.1B). The most often seen are large lipid droplets, which occupy almost the whole cytoplasm of lutein cells (Fig.1C). Moreover, the cytoplasm contains numerous large structures of variable shape and density, concentrated in autophagosomes, whilst other degenerated parts of cytoplasmic membrane structures are twisted and form myelin-like inclusions (Fig.1D). Macrophages and fibroblasts were observed in close vicinity with degenerated lutein cells (Fig.1A). 

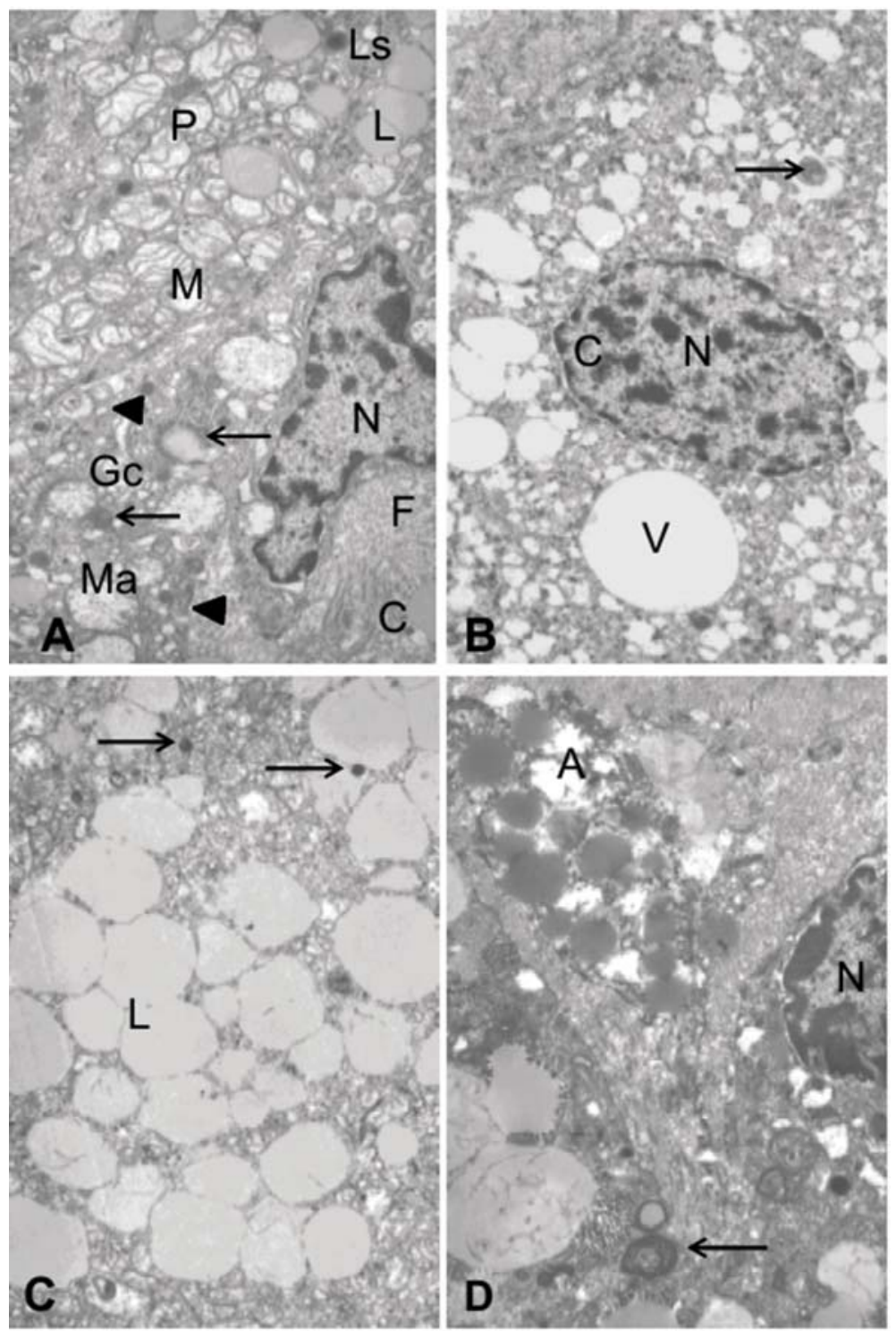

Figure 1. Ultrastructural changes in lutein cells of the CL in dairy cows of BCS1 and BCS2 (x 7200). A. Swelling of mitochondria (M), disruption of cristae and partial disintegration of the membranes. In their close vicinity there are lysosomes (Ls), peroxisomes $(\mathrm{P})$ and lipids $(\mathrm{L})$. Fibroblast $(\mathrm{F})$ with the nucleus $(\mathrm{N})$ and collagen fibrils $(\mathrm{C})$. In the middle, the part of a macrophage cytoplasm (Ma) with phagolysosomes (arrows), vacuoles after endocytosis (arrowheads), Golgi complex (Gc) and lysosomes (Ls). B. Degeneration of smooth endoplasmic reticulum with the formation of small vesicles, large vacuoles $(\mathrm{V})$ and myelin structures (arrow). The nucleus $(\mathrm{N})$ with the clumping of nuclear chromatin (C). C. Numerous large lipid droplets (L) in close vicinity with lysosomes (arrows) in the cytoplasm of lutein cell. D. Numerous large dark structures of variable shape concentrated in autophagosomes (A), the degenerated fragments of membranes are twisted and form myelin-like inclusions (arrow). Nucleus (N) with clumping of nuclear chromatin. 


\section{Ultrastructure of luteal cells from cows of BCS 3 (moderate condition)}

In this group the ultrastructural status of lutein cells was highly variable. However, in the cytoplasm the dominant organelles were small and large lipid droplets, often occurring in close vicinity with the heterochromatic nucleus, which has an irregularly waved surface and markedly dilated nuclear envelope (Fig. 2A). We observed the changes in the smooth endoplasmic reticulum, numerous small vesicles of variable size, giant whorls of tubular smooth membrane structures and cytoplasm vacuoles (Fig.2A,B) as well as clustered and swollen mitochondria (Fig. 2A,C). Numerous autophagosomes are seen in the cytoplasm together with lysosomes and peroxisomes (Fig. 2D). Bundles of collagen fibrils surround degenerated lutein cells with karyorhexic nucleus (Fig. 2D).
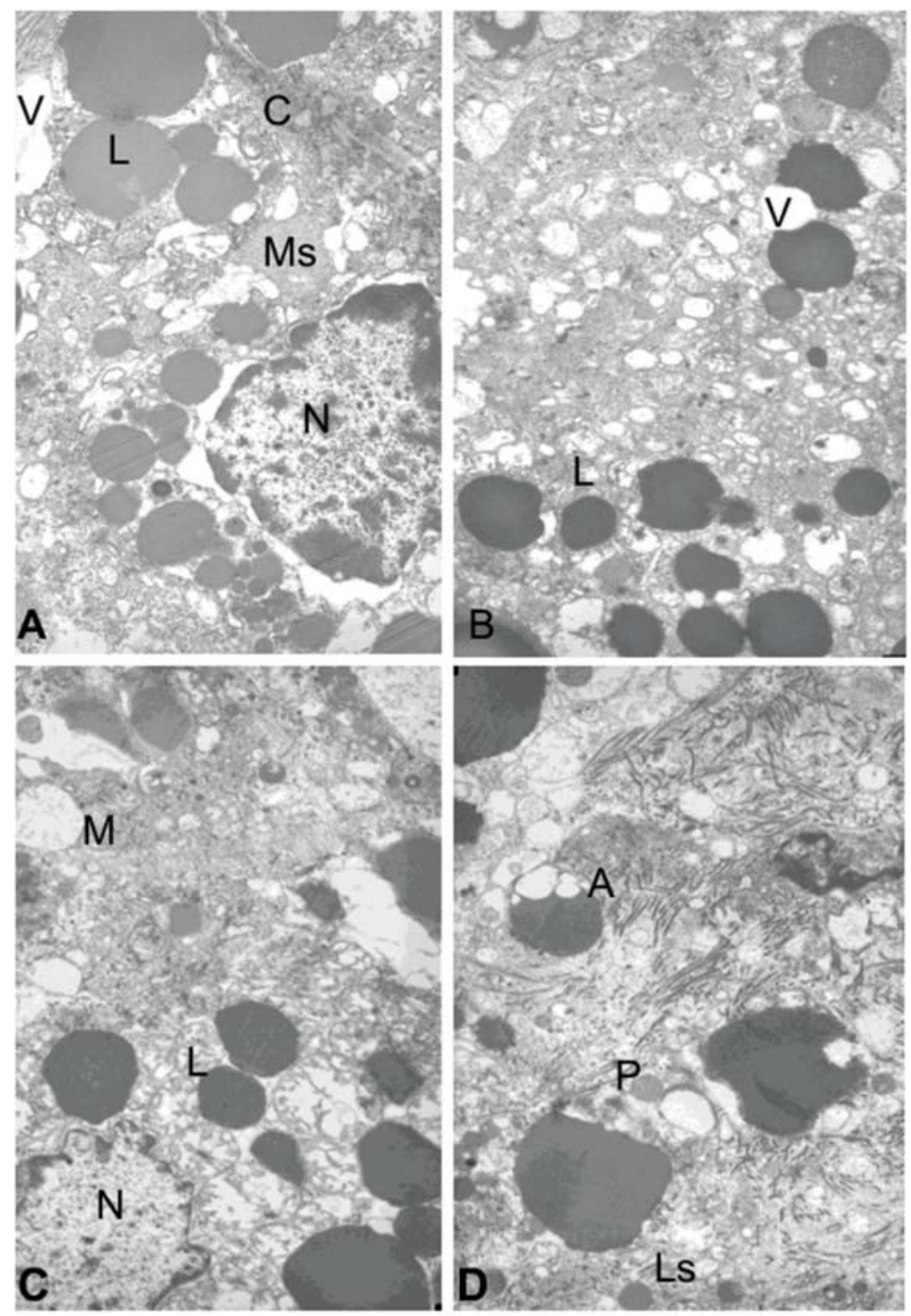
Figure 2. Ultrastructural changes in lutein cells of the CL in dairy cows of BCS 3 (x7200). A. Well-defined electron-dense large lipid droplets (L) are present in lutein cells of corpora lutea after staining with p-phenylenediamine. The nucleus $(\mathrm{N})$ with hyperchromatosis of karyolemma, the vacuoles (V), smooth membrane structures (Ms) and collagen fibrils (C) are visible. B. Occurrence of numerous small vesicles and large vacuoles (V) in lutein cells of the corpora lutea in tight junction with lipid droplets (L). C. Accumulation of swollen mitochondria $(M)$ in a close vicinity with lipid droplets $(L)$; shrunken nucleus $(N)$ is visible in the cytoplasm of corpus luteum cells. D. Autophagosomes (A) are visible together with lysosomes (Ls) a peroxisomes (P) in lutein cells.

\section{Ultrastructure of luteal cells from cows of BCS4/BCS5 (fattening)}

Degeneration of smooth endoplasmic reticulum is associated with increased accumulation of membranes and significant formation of vacuoles and myelin structures (Fig. 3A). An increased incidence of lysosomes and myelin structures was observed in the cytoplasm of lutein cells (Fig. 3B). It was also observed that autolysosomes of different size contain lipids in form of numerous fat granules and accumulated black osmophylic matter (Fig. 3C). Regressing lutein cell nuclei show irreversible changes in form of hyperchromatosis and pyknosis. The cytoplasm contains numerous myelin structures (Fig. 3C). Also in the corpora lutea similar accumulation of fibroblast cells is observed (Fig. 3D). Portions of degenerating lutein cells are phagocytosed by macrophages (Fig. 3E).

\section{Ultrastructural morphometric measurements}

Ultrastructural morphometric analysis of the lutein cells of bovine corpora lutea demonstrates different occurrence of cell organelles and cytoplasm inclusions in cows of BCS 1, 2, 4 and 5 in comparison to the cows of BCS 3 (moderate condition) (Table 1). Lipid relative volume was higher in the BCS1 group and had a decreasing trend as the BCS value was growing from 1 to 5 . However, in BCS1 and BCS2 groups relative volume of lipids was significantly higher compared to BCS4 and BCS5. Significant difference was also noted between BCS3 and BCS4 groups compared to BCS5, whilst the difference between BCS3 and BCS4 groups was not significant. There was significant difference recorded in the vacuole occurrence between BCS1-3 and BCS4 or BCS5, whilst difference between BCS4 and BCS5 was not significant. The occurrence of lysosomes was increased as BCS value elevated from 1 to 4 . Significant difference was found between BSC1 and 2 compared to BCS3 and BCS4. In the peroxisome occurrence a significant difference was found between BCS1-3 in comparison with BCS4 or BCS5. Significantly higher incidence of autophagosomes was recorded in the BCS1 group when compared to other four groups (BCS2- BCS5); there was a growing trend when BCS value was increased from 1 to 4 . In the BCS5 group the incidence of autophagosomes was slightly higher than in the BCS4 group. Differences in lipofuscin occurrence between BCS groups were insignificant.

The results of ultrastructural morphometria demonstrate significant elevation $(\mathrm{P}<0.05)$ in the relative volume of lipids in the lutein cells of emaciated cows (BCS1) or in cows with a tendency to emaciation (BCS2). However, in cows with a tendency to fattening 
(BCS4) or in fattened cows (BCS5) the relative volume of vacuoles, lysosomes and autophagosomes was significantly increased $(\mathrm{P}<0.05)$.
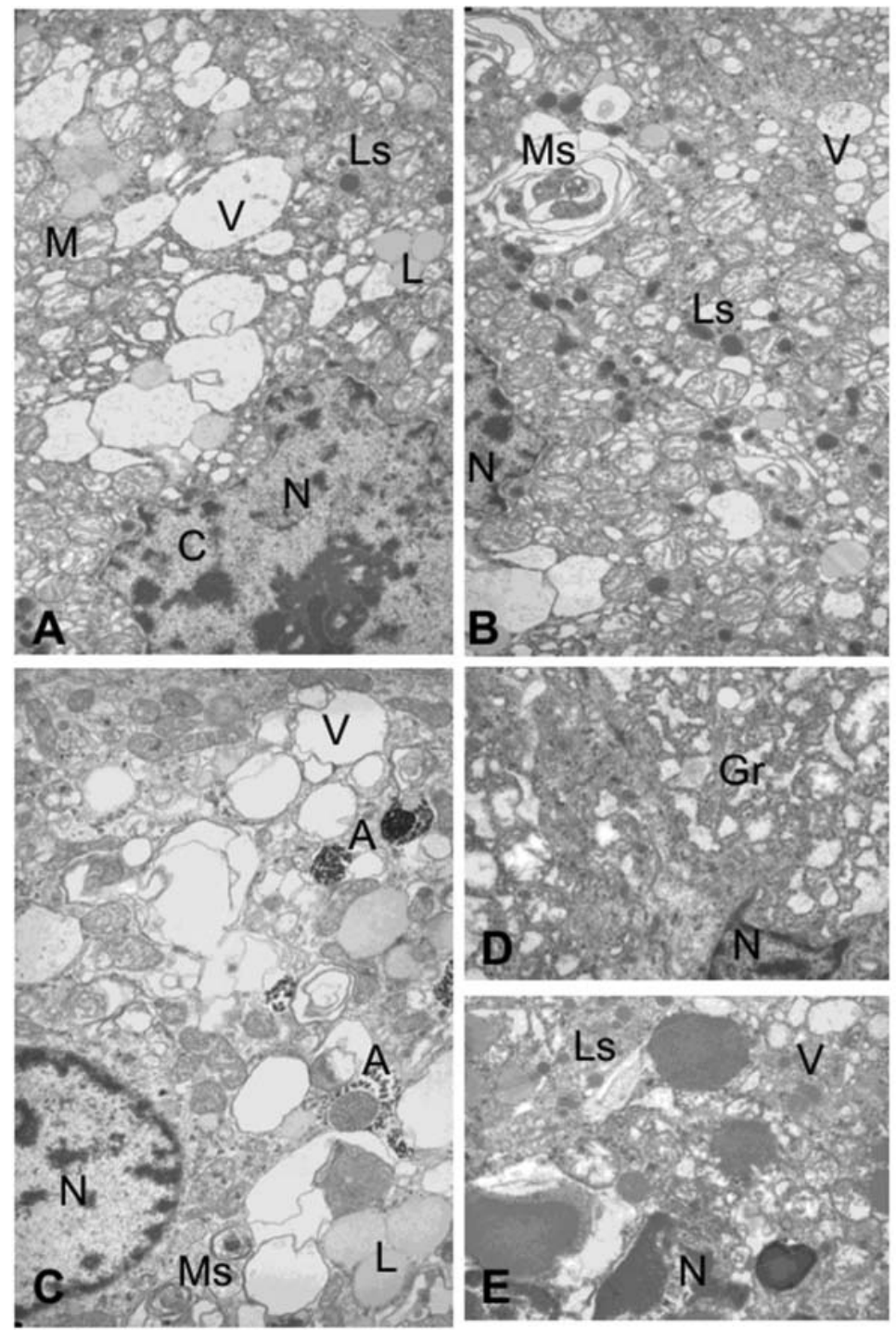

Figure 3. Ultrastructural changes in a lutein cell of the CL in dairy cows BCS4 and BCS5 (x 7200). A. Intense occurrence of vacuoles $(V)$, degenerated smooth endoplasmic reticulum, swollen mitochondria (M) with cristae disruption, lysosomes (Ls) and lipids (L). The nucleus $(\mathrm{N})$ showing clumping of nuclear chromatin (C). B. Increased occurrence of lysosomes (Ls), myelin structures (Ms), vacuoles $(\mathrm{V})$ and swollen mitochondria $(\mathrm{M})$ are visible. The nucleus $(\mathrm{N})$ with clumping of nuclear chromatin. C. Large autophagosomes (A) with granular osmophilic matter are present in the cytoplasm of luteal cells along with myelin structures (Ms), vacuoles (V) and lipids (L). The nucleus $(\mathrm{N})$ and mitochondria with tubules are visible. D. Fibroblastic cell with well-developed granular endoplasmic reticulum (Gr) and the nucleus $(\mathrm{N})$ in the cytoplasm. E. Macrophage with the nucleus $(\mathrm{N})$ forming invaginations. Numerous lysosomes (Ls), phagolysosomes and vacuoles (V) after endocytosis are present in the cytoplasm of lutein cells. 
Table 1. Ultrastructural morphometry (relative volume in \%) of lutein cell in corpus luteum of cows with different (BCS)

\begin{tabular}{lccccc}
\hline \multirow{2}{*}{$\begin{array}{l}\text { Organelles } \text { inclusion } \\
\text { intoplasmic }\end{array}$} & $\mathbf{5}$ & $\mathbf{2}$ & $\mathbf{3}$ & $\mathbf{4}$ & $\mathbf{5}$ \\
\cline { 2 - 6 } Lipids & $37.6 \pm 8.9^{\mathrm{a}}$ & $34.4 \pm 7.4^{\mathrm{a}}$ & $30.1 \pm 15.1^{\mathrm{a}}$ & $21.8 \pm 4.0$ & $13.9 \pm 1.0$ \\
Vacuoles & $7.2 \pm 1.5^{\mathrm{a}}$ & $8.0 \pm 2.3^{\mathrm{a}}$ & $7.3 \pm 1.3^{\mathrm{a}}$ & $20.8 \pm 4.8$ & $23.0 \pm 2.2$ \\
Lysosomes & $3.8 \pm 0.5^{\mathrm{a}}$ & $4.7 \pm 0.9^{\mathrm{a}}$ & $7.4 \pm 1.1$ & $8.3 \pm 1.3$ & $6.7 \pm 2.2^{\mathrm{a}}$ \\
Peroxisomes & $1,1 \pm 0,4^{\mathrm{a}}$ & $0.8 \pm 0.3^{\mathrm{a}}$ & $1.1 \pm 0.4^{\mathrm{a}}$ & $2.8 \pm 0.8$ & $4.4 \pm 1.4$ \\
Autophagosomes & $3.8 \pm 1.0^{\mathrm{a}}$ & $9.7 \pm 2.3$ & $13.7 \pm 2.4$ & $17.9 \pm 2.6$ & $17.6 \pm 3.6$ \\
\hline Lipofuscin & $0.7 \pm 0.3$ & $1.0 \pm 0.4$ & $1.4 \pm 0.4$ & $0.6 \pm 0.3$ & $1.6 \pm 0.6$ \\
\hline
\end{tabular}

The data are expressed as the means \pm standard error of the mean (SEM). Different letters within the rows indicate significant differences at $\mathrm{P}<0.05$ (one-way ANOVA).

\section{DISCUSSION}

In the absence of luteotrophic signal, bovine luteal cells on the 14th day of the estrous cycle are subjected to regression, which is characterized by the reduction in progesterone (P4) production (functional luteolysis) and tissue degeneration by apoptosis (structural luteolysis) [14]. Luteolysis is characteristic by regressive changes in the lutein cells with the incidence of pyknotic nuclei, vesiculation of agranular endoplasmic reticulum, the reduction in the relative volume of mitochondria with tubes and increase in the relative volume of lysosomes, autophagosomes and cytoplasmic lipids. Significantly increased occurrence of lipids in cows with BCS1 and BCS2 was found also in our study, which indicates on the involvement of regressive mechanisms. Similar results were obtained also by Fraser et al. [15], who found that natural luteolysis in primates was associated with lutein cell atrophy, condensation of cytoplasmic inclusions and organelles and increase in relative volume of lipids.

Increased occurrence of myelin structures in cows of BCS1 and BCS2 may be associated with the degeneration of smooth endoplasmic reticulum and is similar to those published by Fraser et al [15], where the treatment with GnRH resulted in aggregations of smooth membranes and myelin-like bodies in the degenerated cytoplasm of the lutein cells. In dairy cows with a tendency to fattening and in fattened cows (BCS4 and 5) significantly increased incidence of vacuoles, lysosomes and autophagosomes was observed. These observations are similar to the data of Fraser et al. [15] following prostaglandin treatment: the lutein cells contained numerous small and large vesicles; as the degenerative changes advanced, these vesicles coalesced into alveolar-type vacuoles, and the nuclei were involuted. In autophagosomes of BCS4 and BCS5 cows we often observed granulated osmophilic matter, which probably represented undigested fat, suggesting on the lack of lipase in lysosomes.

Although peroxisomes play an important role in the lipid and steroid metabolism of lutein cells, their occurrence in cows of BCS4 and BCS5 groups was only insignificantly 
increased. Peroxisomes in our samples were of ovoid shape, about $0.2-0.5 \mu \mathrm{m}$ in size, surrounded by the membrane and contained finely granulated matter without central nucleoid (Fig. 2D). The importance of peroxisomes was confirmed by Viergutz et al. [16], who proved that the activity of peroxisome proliferator-activated receptors (PPAR gamma) plays a role in the arrest of the cell cycle in lutein cells of cows to maintain their differentiated state. Also, in pseudopregnant rabbits PPAR gamma can regulate the genes required for follicles and corpus luteum maintenance [17].

Fibroblasts, that were observed in our lutein cell samples (Fig. 3D), are involved in the formation of connective tissue, what is evidenced by the presence of numerous collagen fibres. This observation is in concert with the data of Irving-Rodgers et al. [18], who also found collagen and laminin fibres in the intercellular space between lutein cells of human cyclic corpus luteum.

Macrophages are actively involved into phagocytosis of degenerated lutein cells. In our study, fibroblasts and macrophages were found in the corpus luteum of cows from each BCS group (Fig.3 D,E). It was found that luteal cells, undergoing apoptosis at the estrous stage, are phagocytosed by macrophages [19,20], and migration of macrophages towards corpora lutea is induced by a MCP-1 chemokine [21], but also by an increased prolactin concentration [22].

Accumulation of autophagosomes induces luteal cell apoptosis. Autophagy is involved in rat luteal cell death through apoptosis, and is most prominent during corpus luteum regression [23]. On the basis of the report [15] we assume, that in dairy cows of different body condition, the death of lutein cells during luteolysis involves cell atrophy with phagocytosis of cytoplasmic debris. Therefore, typical apoptotic-like nuclei of lutein cells rarely occurred. These considerably atrophied lutein cells are degraded by lysosomes to form autophagosomes. Accumulation of lipids indicates on the cessation of steroidogenesis. These shrunken and fragmented lutein cells are destroyed by macrophages. Increase in number of vacuoles, lysosomes, peroxisomes and autophagic vacuoles (autophagosomes) indicates on initial stages of luteal regression and degeneration in the cytoplasm of lutein cells of cows with BCS 4 and 5, when compared to the BCS 3 cows (Fig.3 A-C).

In conclusions, our observations indicate, that increase in the relative volume of large lipid droplets in the cells of corpus luteum of emaciated cows (BCS1-2), as well as incidence of vacuoles, lysosomes, peroxisomes and autophagosomes in BCS4 and BCS5 cows may evidence for earlier onset of regressive changes in cells of the corpus luteum in comparison to BCS3 cows.

\section{Acknowledgements}

The authors thank to Mrs.V. Šafarova and Z. Hajdakova for preparation and analysis of samples as well as to Dr. Shoubadeep Roychoudhury for language correction of the manuscript. This study was supported by the Agency for the Support of Science and Technology in the Slovak Republic: grants APVV-0137-10 and APVV-14-00-43. The research leading to these results has received funding from the European Community under project no. 26220220180: Building Research Centre 'Agro Biotech’. 


\section{Authors' contributions}

PJ carried out the electron microscopy analyses. MA participated in the design of the study and wrote the manuscript. KE performed the statistical analysis. RJ arranged the animals to BCS groups and prepared the animals for experiments. CP participated in the design and coordination of the study.

\section{Declaration of conflicting interests}

The author(s) declared no potential conflicts of interest with respect to the research, authorship, and/or publication of this article.

\section{REFERENCES}

1. McCracken JA, Custer EE, Lamsa JC: Luteolysis: a neuroendocrine-mediated event. Physiol Rev 1999, 79: 263-324.

2. Skarzynski DJ, Ferreira-Dias G, Okuda K: Regulation of luteal function and corpus luteum regression in cow: hormonal control, immune mechanisms and intercellular communication. Reprod Dom Anim 2008, 43 Suppl 2: 57-65.

3. Rueda BR, Hendry IR, Hendry WJ, Fong HW, Stormshak F, Slayden OD, Davis JS: Decreased progesterone level and progesterone receptors antagonists promote apoptotic cell death in bovine luteal cells. Biol Reprod 2000, 62: 269-276.

4. Peter AT, Levine H, Drost M, Bergfelt DR: Compilation of classical and contemporary terminology used to describe morphological aspects of ovarian dynamic in cattle. Theriogenol 2009, 71: 1343-1357.

5. Fields MJ, Fields PA: Morphological characteristics of the bovine corpus luteum during the estrus cycle and pregnancy. Theriogenol 1996, 45: 1295-1325.

6. Opsomer G, Grohn YT, Hertl J, Coryn M, Deluyker H, DeKruif A: Risk factors for post partum ovarian dysfunction in high producing dairy cows in Belgium: a field study. Theriogenol 2000, 53: 841-857.

7. Petersson KJ, Gustafsson H, Strandberg E, Berglund B: A typical progesterone profiles and fertility in Swedish dairy cows. J Dairy Sci 2006, 89: 2529-2538.

8. Ferguson JD: Nutrition and reproduction in dairy herds. Vet Clin North Am Food Anim Pract 2005, 21: 325-347.

9. Odde KG, Ward HS, Kiracofe GH, Mckee RM, Kittok RJ: Short estrous cycles and associated serum progesterone levels in beef cows. Theriogenol 1980, 14: 105-112.

10. Stankiewicz T, Blaszczyk B: Concentrations of bone morphogenetic protein-15 (BMP15 ) and growth differentiation factor-9 (GDF-9) in follicular cysts, mono- and polyoocyte follicles in gilts. Acta Vet Beograd 2014, 64: 24-32

11. Edmonson AJ, Lean IJ, Weaver LD, Farver T, Webster G: A body condition scoring chart for Holstein dairy cows. J Dairy Sci 1989, 72: 68-78.

12. Boshier DP, Holloway H, Kitchin LF: A comparison of standard lipid staining techniques used in electron microscopic studies of mammalian tissues. Stain Technol 1984, 59: 83. 
13. Weibel ER: Principles and methods for morphometric study of the lung and other organs. Lab Invest 1963, 12: 131-155.

14. Juengel JL, Garverick HA, Johnson AL, Youngquist RS, Smith MF: Apoptosis during luteal regression in cattle. Endocrinol 1993, 132: 249-254.

15. Fraser HM, Lunn SF, Harrison DJ, Kerr JB: Luteal regression in the primate: different forms of cell death during natural and gonadotropin-releasing hormone antagonist or prostaglandin analogue-induced luteolysis. Biol Reprod 1999, 61: 1468-1479.

16. Viergutz T, Loehrke B, Poehland R, Becker F, Kanitz W: Relationship between different stages of the corpus luteum and the expression of the peroxisome proliferator-activated receptor $\gamma$ protein in bovine large lutein cells. J Reprod Fert 2000, 118: 153-161.

17. Zerani M, Maranesi M, Brecchia G, Gobbetti A, Boiti C, Parillo F: Evidence for a luteotropic role of peroxisome proliferator-activated receptor gamma: expression and in vitro effects on enzymatic and hormonal activities in corpora lutea of pseudopregnant rabbits. Biol Reprod 2013, 88: 1-9.

18. Irving-Rodgers HF, Friden BE, Morris SE, Mason HD, Brannstrom M, Sekiguchi K, Sanzen N, Sorokin LM, Sado Y, Ninomiya Y, Rodgers RJ: Extracellular matrix of the human cyclic corpus luteum. Mol Hum Reprod 2006, 12: 525-534.

19. Nagaosa K, Shiratsuchi A, Nakanishi Y: Determination of cell type specificity and estrus cycle dependency of monocyte chemoattractant protein-1 expression in corpora lutea of normally cycling rats in relation to apoptosis and monocyte/macrophage accumulation. Biol Reprod 2002, 67: 1502-1508.

20. Kato S, Shiratsuchi A, Nagaosa K, Nakanishi Y: Phosphatidylserine- and integrin-mediated phagocytosis of apoptotic luteal cells by macrophages of the rat. Dev Growth Differ 2005, 47: 153-161.

21. Nagaosa K, Shiratsuchi A, Nakanishi Y: Concomitant induction of apoptosis and expression of monocyte chemoattractant protein 1 in cultured rat luteal cells by nuclear factor $\mathrm{kB}$ and oxidate stress. Dev Growth Differ 2003, 45: 351-359.

22. Bowen JM, Keyes PL, Warren JS, Townson DH: Prolactin-induced regression of the rat corpus luteum: Expanssion of monocyte chemoattractant protein-1 and invasion of macrophages. Biol Reprod 1996, 54: 1120-1127.

23. Choi JY, Jo MW, Lee EY, Choi DS: The role of autophagy in corpus luteum regression in the rat. Biol Reprod 2011, 85: 465-472.

\title{
ULTRASTRUKTURNE POROMENE CIKLIČNOG ŽUTOG TELA KOD MUZNIH KRAVA SA RAZLIČITIM TELESNIM KONDICIJAMA
}

\author{
PIVKO Juraj, MAKAREVICH V. Alexander, KUBOVIČOVA Elena, \\ RAFAY Jan, CHRENEK Peter
}

Cilj studije je bio da se definišu ultrastrukturne promene u ovarijalnom ciklusu žutog tela (CL) muznih krava koje su imale različite skorove telesne kondicije (BCS, petostepena skala). Ovarijumi su uzimani sa linije klanja, od holštajn muznih krava koje su 
imale telesnu kondiciju BCS1 (izražena kaheksija; n=4), BCS2 (tendencija ka kaheksiji, $\mathrm{n}=4$ ), BCS3 (prosečna telesna kondicija, $n=4$ ), BCS4 (tendencija ka tovu; $n=4$ ) i BCS5 (utovljene krave; $n=4$ ). Prosečno su krave bile starosti: 6.2, 4.1, 5.7, 5.5 i 6.36 godina $i$ to za BCS1, BCS2, BCS3, BCS4 odnosno BCS5. U cilju ispitivanja elektronskom mikroskopijom, funkcionalna CL u sredini lutealne faze, fiksirana su u rastvoru aldehida i posle toga u 1\% rastvoru OsO4. Radi vizualizacije lipida, uzorci su potapani u 1\% rastvor fenilendiamina u acetonu. Durcupan ultratanki isečci $(90 \mathrm{~nm})$ su uz upotrebu uranil acetata i olovo citrata, ispitivani upotrebom Jeol transmisionog elektronskog mikroskopa. Pojava ćelijskih organela je ustanovljena brojanjem relativne zapremine pojedinačnih ćelijskih komponenti koristeći metodu modifikovane opšte mreže. Osobine lutealne regresije cikličnog CL bile su atrofija luteinskih ćelija, kondenzacija organela i citoplazmatskih inkluzija, povećanje relativnih zapremina vakuola, lizozoma, periksizoma, autofagozoma i lipida. Postojale su značajne razlike $(p<0.05)$ između BCS1, BCS2, BCS4 i BCS5 krava i to u pojavi lipida, vakuola, lizozoma i autofagozoma u lutealim ćelijama u poređenju sa BCS3 kravama. Krave sa skorovima BCS2 ili BCS1, imale su povećane relativne zapremine masnih kapljica, dok su BCS4 i BCS5 krave imale povećanu pojavu (relativna zapremine) vakuola, lizozoma, peroksizoma i autolizozoma. Ovi rezultati ukazuju da luteoliza ciklinčnih CL ima različite karakteristike kod grupa krava sa različitim telesnim kondicijama; kod kahektičnih i utovljenih krava, proces luteolize započinje ranije u poređenju sa kravama koje su prosečnih telesnih kondicija. 